3 Fraher LJ, Adami S, Clemens TL, Jones G, O'Riordan JLH. Radioimmunoassay of 1,25-dihydroxyvitamin $\mathrm{D}_{2}$ : studies on the metabolism of vitamin $\mathrm{D}_{2}$ in man. Clin Endocrinol $(O x f)$ 1983;18:151-65.

4 Ghazarian JG, Jefcoate CR, Knutson JC, Orme-Johnson WH, DeLuca HF. Mitochondrial cytochrome P 450: a component of chick kidney 25-hydroxycholecaliferol-1-hydroxylase. 7 Biol Chem 1974;249:3026-33.
5 O'Riordan JLH, Adami S, Sandler LM, Fraher LJ. Clinical application of radioimmunoassays for vitamin D metabolites. In: Norman AW, Schaefer K, Herrath DV, Grigoleit H-G, eds. Vitamin D: chemical, biochemical and clinical endocrinology of calcium metabolism. Berlin: Walter De Gruyter, 1982:751-6.

(Accepted 22 fune 1988)
Department of Community

Medicine, University

College and Middlesex

School of Medicine,

London WC1E 6EA

P M McKeigue, MFCM,

Wellcome training fellow

M G Marmot, MFCM,

professor

Correspondence and requests for reprints to: Dr McKeigue.

\section{Mortality from coronary heart disease in Asian communities in London}

\section{P M McKeigue, M G Marmot}

In England and Wales in 1970-2 mortality from coronary heart disease was $20 \%$ higher in men and general population. ${ }^{1}$ Asian communities in Britain differ in religious, cultural, geographic, and genetic backgrounds; this diversity is similar to the differences among European populations with differing rates of coronary heart disease. In seeking causes of the high mortality from coronary heart disease in Asians rates for different groups must be established. Analysis of surnames on death certificates suggests that high rates are shared by Gujaratis, Punjabis, southerners, and Moslems, but this method has limitations. ${ }^{2}$

We examined the pattern of mortality in different ethnic groups originating from south Asia by using which one group predominated; five London boroughs were chosen on this basis. In 1982 a survey in Brent and Harrow showed that $77 \%$ of Asians aged over 25 spoke Gujarati. ${ }^{3}$ In a 1985 survey of schoolchildren in Ealing Punjabi speakers accounted for $68 \%$ of those who spoke an Asian language at home; many of the $17 \%$ who spoke Hindi or Urdu also originated from the region that corresponded to Punjab before partition. ${ }^{4}$ Data from the 1981 census show that in Tower Hamlets $80 \%$ of the population born in south Asia and aged 20 and over were born in Bangladesh, and in Waltham Forest $56 \%$ were born in Pakistan. Mortality among Asians in these boroughs was therefore used as an indicator of mortality in Gujaratis, Punjabis, Bangladeshis, and to some extent Pakistanis.

\section{Methods and results}

Tables of deaths by underlying cause (International population figures from the 1981 census were obtained from the Office of Population Censuses and Surveys. Residents born in India, Pakistan, Bangladesh, and Sri Lanka were grouped as Asian; for Brent and Harrow residents born in east Africa were also included in this category. Standardised mortality ratios were calculated for Asians in each borough using the rates for that women who had been born in south Asia than in the districts of residence to distinguish communities in Classification of Disease $410-414$ versus all other) and

borough as the standard and also, to facilitate direct comparison, using the rates for England and Wales in 1981 (table). Standardised proportional mortality ratios compare the observed and expected frequencies with which coronary heart disease is given as the underlying cause on death certificates; they do not depend on census data, and they measure the extent to which excess mortality is specific to a particular disease. Ratios for Asian women in Tower Hamlets and Waltham Forest were based on only a few deaths.

\section{Comment}

National data for mortality by country of birth in 1979-83 are not yet available but, unless the Asian populations that we studied are unrepresentative, mortality from coronary heart disease among Asians in England and Wales has increased by about $25 \%$ since 1970-2. The diminished effects of selection for fitness at migration may account for some of this increase. The economic state of Asian populations in London varies from the comparative affluence of Gujaratis in Brent and Harrow to the deprivation experienced by Bangladeshis in Tower Hamlets. Smoking rates range from very low in Gujarati women in Brent and Harrow ${ }^{3}$ to high in Bangladeshi men in Tower Hamlets. ${ }^{5}$ Most Asians in Brent and Harrow are vegetarian ${ }^{3}$ whereas the Moslem communities of Tower Hamlets and Waltham Forest are generally not. It is therefore striking that Asian men and women in each borough share a mortality from coronary heart disease $50 \%$ higher than the national average. Any general explanation of the high rates of coronary heart disease in south Asians overseas must invoke some factor that is common to the diverse communities that make up the Asian population in Britain.

We are grateful to Mr Brendan Casey and Mr Gurmeet Pooni of North West Thames and North East Thames Regional Health Authorities for producing the tables of deaths.

1 Marmot MG, Adelstein AM, Bulusu L. Immigrant mortality in England and Wales 1970-78. London: HMSO, 1984. (OPCS Studies of Medical and Population Subjects No 47.

2 Balarajan R, Adelstein AM, Bulusu L, Shukla V. Patterns of mortality among migrants to England and Wales from the Indian subcontinent. Br Med $1984 ; 289: 1185-7$.

3 McKeigue PM, Marmot MG, Adelstein AM, et al. Diet and risk factors for coronary heart disease in Asians in north-west London. Lancet 1985; ii: $1086-90$

4 Linguistic Minorities Project. Ealing schools language survey. London: University of London Institute of Education, 1985

5 McKeigue PM, Marmot MG, Syndercombe Court YD, Cottier DE, Rahman S, Riemersma RA. Diabetes, hyperinsulinaemia, and coronary risk factors in Asians in east London. Br Heart $\mathcal{f}$ (in press)

(Accepted 28 fune 1988)

Mortality from coronary heart disease among Asians aged 20-64 in different London boroughs during 1979-83

\begin{tabular}{|c|c|c|c|c|c|c|}
\hline \multirow[b]{2}{*}{$\begin{array}{c}\text { London borough } \\
\text { (predominant Asian ethnic group) }\end{array}$} & \multirow{2}{*}{$\begin{array}{c}\text { No } \\
\text { of } \\
\text { deaths }\end{array}$} & \multicolumn{3}{|c|}{ Standardised to average ( $100 \%)$ for each borough } & \multicolumn{2}{|c|}{ Standardised to average ( $100 \%)$ for England and Wales } \\
\hline & & $\begin{array}{l}\text { Standardised } \\
\text { mortality ratio }\end{array}$ & $\begin{array}{l}95 \% \text { Confidence } \\
\text { interval }\end{array}$ & $\begin{array}{l}\text { Proportional } \\
\text { mortality ratio }\end{array}$ & $\begin{array}{l}\text { Standardised } \\
\text { mortality ratio }\end{array}$ & $\begin{array}{l}95 \% \text { Confidence } \\
\text { interval }\end{array}$ \\
\hline \multicolumn{7}{|c|}{ Men } \\
\hline $\begin{array}{l}\text { Brent and Harrow (Gujarati) } \\
\text { Ealing (Punjabi) } \\
\text { Tower Hamlets (Bangladeshi) } \\
\text { Waltham Forest (Pakistani) }\end{array}$ & $\begin{array}{r}177 \\
118 \\
49 \\
36\end{array}$ & $\begin{array}{l}163 \\
136 \\
118 \\
180\end{array}$ & $\begin{array}{r}138 \text { to } 187 \\
111 \text { to } 161 \\
85 \text { to } 151 \\
121 \text { to } 239\end{array}$ & $\begin{array}{l}146 \\
122 \\
132 \\
121\end{array}$ & $\begin{array}{l}160 \\
147 \\
141 \\
156\end{array}$ & $\begin{array}{l}136 \text { to } 183 \\
120 \text { to } 173 \\
102 \text { to } 180 \\
105 \text { to } 207\end{array}$ \\
\hline \multicolumn{7}{|c|}{ Women } \\
\hline $\begin{array}{l}\text { Brent and Harrow (Gujarati) } \\
\text { Ealing (Punjabi) } \\
\text { Tower Hamlets (Bangladeshi) } \\
\text { Waltham Forest (Pakistani) }\end{array}$ & $\begin{array}{r}33 \\
30 \\
2 \\
7\end{array}$ & $\begin{array}{l}157 \\
173 \\
106^{\star} \\
318^{\star}\end{array}$ & $\begin{array}{l}103 \text { to } 211 \\
111 \text { to } 235\end{array}$ & $\begin{array}{l}145 \\
158 \\
136^{\star} \\
268^{\star}\end{array}$ & $\begin{array}{l}160 \\
206 \\
108^{\star} \\
217^{\star}\end{array}$ & $\begin{array}{l}105 \text { to } 215 \\
132 \text { to } 280\end{array}$ \\
\hline
\end{tabular}

$\star$ Ratio calculated from small numbers. 